\title{
ATTITUDES TOWARDS DEMOCRACY IN BULGARIA: THE IMPORTANCE OF SOCIAL INEQUALITY
}

\author{
Zhivko Minkov \\ New Bulgarian University, Sofia, Bulgaria
}

\begin{abstract}
This research is an attempt to examine the developmental relationship between democracy and the socioeconomic conditions in Bulgaria. The assumption is that one of the factors contributing to the negative attitude towards democracy in Bulgaria is the high level of social inequality. After discussing the relevance of studying democracy and socioeconomic conditions from a developmental perspective, the paper traces the socioeconomic development of Bulgaria from 1989 to date and examines public perceptions of social inequality in the country. The research has not revealed any overall negative public attitude towards democracy in Bulgaria. However, the findings have demonstrated a clear tendency for the public support for democracy to decline reflecting the growth of social inequality.
\end{abstract}

Keywords: democracy, attitude, Bulgaria, socioeconomic conditions, inequality, poverty

\author{
Article history: \\ Received: 17 September 2019; \\ Reviewed: 18 November 2019; \\ Revised: 4 December 2019; \\ Accepted: 20 December 2019; \\ Published: 30 December 2019 \\ Copyright (c) 2019 Zhivko Minkov
}

(7) (8) This open access article is published and distributed under a CC BY-NC 4.0 International License which permits non-commercial use, distribution, and reproduction in any medium, provided the original author and source are credited. Permissions beyond the scope of this license may be available at iminkov@nbu.bg. If you want to use the work commercially, you must first get the authors' permission.

Citation: Minkov, Z. (2019). Attitudes towards Democracy in Bulgaria: The Importance of Social Inequalities. English Studies at NBU, 5(2), 323-349. https://doi.org/10.33919/esnbu.19.2.8

Zhivko Minkov, $\mathrm{PhD}$ is a member of the department of Political Sciences at New Bulgarian University. His main research areas are social policy, European social policy, social inequalities and quality of democracy, and pension policy.

E-mail: jminkov@nbu.bg

https://orcid.org/0000-0001-5417-6528

The research is based partly on the information from several representative polls, conducted by the sociological agencies Mediana and Sova-Harris for the period 2010-2014. The polls were ordered from the Project "Quality of democracy in Bulgaria: democratic consent and civil participation" carried out by the department of Political Sciences at New Bulgarian University and financed by the National Science Fund (NSF) of the Ministry of Education and Science, Bulgaria, Grant number: ДТК 02/17/16.12.2009 


\section{Social environment and the study of democracy}

The first step in this paper is to formulate answers to a crucial and challenging question: "How relevant is the study of Bulgaria's democracy through the prism of social inequalities?" Delving into this question inevitably brings the argumentation forth into the broader field of democracy studies. It is worth noting that democracy studies have offered conflicting views regarding any possible answers.

In the majority of existing approaches, the correlation between socioeconomic environment and democracy has been considered irrelevant. Thus, both early studies (Schumpeter, 1943) and contemporary ones (Huntington, 1991) have been based upon the idea that an election system is the essence of democracy. In Polyarchy, Dahl (1971) expanded the core essence of "elective democracy" with equal rights of participation in elections and the presence of civil and political rights allowing for free association, dissemination of and access to information relevant to participation in elections and political decision-making. According to Dahl (1971), the existence and proper operation of these sets of rights and institutions embody the two essential elements of democracy: freedom and equality. Dahl also proposed another element that he considers not merely an essence of democracy but also crucial to its functioning: participation in politics, construed as both voting in elections and as the broader involvement in important political decision-making.

Dahl's concept of 'participatory democracy' laid the groundwork for a multitude of comparative international studies and simultaneously stimulated new developments in the field, focusing on comparing democracies, i.e. the degree to which existing democracies guarantee political participation and uphold freedom and equality. An array of authors such as O'Donnell (1998, 2004), Morlino (2004), Lauth $(2000,2004)$, Diamond (1999), Hadenius (1992) and others have elaborated extensive research concepts aiming to achieve a deeper level of comparison. Regardless of the differences between these approaches, they are mostly unified by being tied to an expanded but essentially political notion of democracy. It is constructed around the rationale that the essence and stability of democracy are expressed by the degree to which freedom and equality are guaranteed; more specifically, freedom and autonomy of the individual (freedom of action, protection from government intrusion, equality before the law, 
inalienable rights, free expression of will, etc.), and political equality (equal participation in the political process, the right to elect and be elected, the right to information, the right to control the government, etc.). From this perspective, public welfare and the distribution of wealth are not regarded as primary goals or essential elements of democracy, but rather as issues that should be resolved via the democratic mechanisms guaranteeing the broadest possible civil participation in politics and political decision-making.

There is another approach to democracy studies, which is crucial to this study. Its principal foundations have been laid by Lipset (1981), Sen (1979), Held (1996), Heller (1934), Rawls (1971), Rueschemeyer (2004), Meyer (2011), Merkel (2004) etc. Despite significant differences, all of these authors base their conclusions on a very broad definition and understanding of democracy. It includes the elements of both electoral and participatory democracy but emphasizes citizens' social conditions, treating them as vital for a fair, all-inclusive and meaningful civil participation in politics (Bühlman, Merkel, Wessels \& Müller, 2007, p. 5). For instance, it was Lipset (1981, p. 31) who first formulated the now-classical relation between socio-economic environment, poverty and democracy. In his own words, "The more well-to-do a nation, the greater the chance that it will sustain democracy". In this particular case, Lipset views high levels of prosperity and low levels of poverty not as essential elements of democracy, but as important prerequisites for its stability and sustainability in the face of radical political ideas and/or destabilizing class conflicts.

Sen (1979; 1996), Held (1996), Heller (1934), Rawls (1971), Rueschemeyer (2004) and Meyer (2011) have formulated a different notion. For them, the mere legal establishment of civil and political rights, without the presence of a social footing for their genuine support, cannot guarantee the correct functioning of democracy and/or its complete establishment. Consequently, they claim that governments must guarantee the resources necessary for the genuine existence and exercising of these rights to the largest possible number of citizens. This approach maintains that resources and goods must be deliberately redistributed within society (i.e. civil and political rights must be expanded and reinforced by social rights); it is this redistribution that makes democracy as complete as possible through the practical integration and inclusion of 
the vast majority of citizens in democratic procedures (Bühlman et al., 2007, p. 5). For example, according to Rueschemeyer (2004, pp. 76-90) ${ }^{1}$, the presence of inequalities in extra-political areas (such as economics or the discrepancies between available resources and access to goods caused by market forces) has a considerable direct and indirect impact on politics and essentially constrains political equality and participation. If these groups of influences appear to be extremely broad, the measures (interventions) proposed for mitigating their negative impact are even more diverse, stepping beyond the boundary of pure redistribution of material welfare (income). They include measures for providing genuine equal access to political processes and procedures (e.g. equal public funding of electoral candidates, guaranteeing equal media time coverage, etc.); for guaranteeing sufficient cultural, social and educational resources (the right to education irrespective of social status, the right to information and access to information, etc.), which provide all citizens with an equal opportunity for active participation.

Despite forming an integral part of the tradition of democracy studies, this trend seems to have lost its topicality during the last decades of the $20^{\text {th }}$ century. The reasons for this are manifold and complex. The collapse of socialist regimes, the ascent and prevalence of the neoliberal ideology, and the evolution of a global economy have all eroded the acceptability and relevance of this doctrine of democracy. The wide dissemination of free market ideas, the questioning of interventionist and redistributive policies by the social state, and the increasingly popular belief, even in academic circles, in the ultimate triumph of democracy as the only model for sustainable social progress have undermined the authority of this approach and the attention to its analytical value. Paradoxically, the topical question about the quality of democracy that emerged at the turn of the $21^{\text {st }}$ century, has led to the re-emergence of the issue of the influence of social inequalities in democracy studies. At the end of the $20^{\text {th }}$ century, the euphoria

\footnotetext{
${ }^{1}$ Within this broad framework, he focuses on a variety of aspects: opportunities for groups possessing dominant economic and social resources to gain an advantage in the electoral process owing to these resources; opportunities for dominant groups to exert a cultural hegemony, i.e. to shape directly and indirectly the views, values and preferences of subordinate groups through their control over information channels (media) and/or socialization systems (education, culture), etc., by blocking the legitimization of opposing interests, values or opinions; or the impact of socio-economic inequalities as a factor that limits not only the actual equal participation in political life but also leads to an overall exclusion from all areas of public life.
} 
from the Third Wave of democratization subsided, giving way to soberer evaluations of democratic results, if not outright disappointment and dissatisfaction. The conclusion that only a portion of the transitions underway have led to the establishment of an effective democratic rule broadened the focus of research toward the issue of democracy consolidation (Erdmann \& Kneuer, 2011, p. 9). The results were twofold. On the one hand, there emerged the necessity for a differentiated conceptualization of democracy to encompass its diverse experiences and outcomes and the justification for genuinely existing subtypes: the so-called 'democracies with adjectives' (Collier \& Levitsky, 1996, p. 1). On the other hand, emphasizing the issue of consolidation and the quality of democracies stimulated the return to wider, more complex notions in democracy studies encompassing a greater variety of factors and dependencies. This allows me to speak about an increasing topicality of the questions related to social inequalities and the study of democracy.

An instance of that is Wolfgang Merkel's conception of studying and appraising democracy: embedded democracy. Merkel builds upon the rationale that besides the prerequisite of 'free elections', we must also include those partial regimes of the political system which guarantee that elections are meaningful (Hadenius, 1992). In other words, the presence of an institutional guarantee that democratically elected representatives will use their power in compliance with the principles of democracy and the law in the periods between elections. Merkel defines five partial regimes: regime of democratic elections, regime of rights to political participation, regime of civil rights and liberties, institutional guarantee of control over the government (horizontal accountability), and de jure and de facto guarantee that democratically elected representatives 'govern effectively' (Merkel, 2004, pp. 36-43). Particularly relevant to this report is Merkel's general premise that stable, law-abiding democracies are doubly secured. First, the regular operation of the abovementioned partial regimes (the balance between their interdependency and independence) guarantees internal stability and sustainability. Second, Merkel believes that the partial regimes are situated inside rings of extrademocratic factors, which benefit democracy and safeguard it against external and internal shocks and destabilization. Drawing from the premises of the theory of political systems, Merkel (2004, p. 44) defines the following external rings: socio-economic environment, civil society, and international integration of the state (stateness). 
Merkel justifies the significance of the socio-economic environment with respect to democracy in a fairly wide context. His first foundation is the interrelation between high levels of prosperity and the prospects of democratic stability demonstrated by Lipset. Merkel (2004, p. 44) adopts the impact, as proven in numerous studies, of positive economic development and prosperity on the sustainability and consolidation of democracy, without, however, imposing it as an essential prerequisite for the existence of democracy or the improvement or deterioration of its quality. His second, equally important foundation interprets the socio-economic environment as the effect of social inequalities on democracy, and in particular on political equality and participation. The general premise holds that if the unequal distribution of resources and welfare leads not only to considerable diversity in citizens' income and welfare access but also drives a major number of citizens below the line of poverty, then this will affect democracy negatively (Merkel, 2004, p. 44). The negative effects are directly linked to violating the principles of participation and equal political rights: the lack of sufficiently homogeneous economic basis or the presence of widespread poverty restricts the access to various resources and prerequisites (material and social resources, such as education, culture, a broad social network, and access to information) that are vital for the existence of active and aware citizens. Therefore, if the principle of political equality is inextricably bound to the principle of democracy, then both principles are threatened when equal political rights cannot be guaranteed because of extreme socio-economic inequalities (Merkel, 2004, p. 44).

The presentation so far provides several major arguments for the relevance of studying democracy across the prism of the socio-economic environment and social inequalities. It seems appropriate to list them in an order that highlights their importance with respect to democracy. As demonstrated, the inclusion of such a correlation (social inequalities - democracy) is not alien or novel to existing traditions in democracy studies. Although formal, this first argument entails a second one, which I consider to be the most essential one. It holds that the entire development of democratic societies (including European ones) has provided us with enough grounds to update democracy studies in correlation with social inequalities. The facts underlying this presumption are symptomatic. 
The last few decades have been a time of development characterised by a constant growth of inequalities and an increasing range and intensity of the risk of poverty and social exclusion. These processes, to a varying degree, have been affecting both so-called new democracies and old democracies. In fact, it appears that for the first time in recent history, reality has refuted the axiom, hitherto universally accepted and supported by multiple studies, that democracy leads to a significant 'shrinking' of social inequalities. Democratic regimes themselves are currently caught in a radically new environment of existence and evolution. This is precisely what necessitates appraising the characteristics of the new environment and looking for its potential impact on the evolution of democracy. Thirdly, the rationalization, examination and evaluation of democracy through the prism of socio-economic development and social inequalities gains an additional relevance and value when applied to so-called new democracies in states like Bulgaria-especially considering the great burden and social disruption caused by the overall democratization process. Just as important is the fact that even countries like Bulgaria who have accomplished the transition demonstrate contradictory trends in their social development (including their economic evolution) and can be validly called societies with deepening inequality, poverty and exclusion. From the perspective of democracy studies, the 'Bulgaria case' represents a combination of two overlapping factors: a relatively recent transition to democracy, and a considerable amount of social inequalities.

\section{Dynamics in the evolution of social inequalities in Bulgaria}

The examination of the leading socio-economic characteristics (economic development and social inequalities) in Bulgaria is subject to the necessity to describe a significant part of the environment that is considered an 'external ring' of democracy. Therefore, I am looking for factors in this 'external ring' that may benefit and reinforce or, alternatively, destabilize and damage Bulgarian democracy. To this end, I have employed several standardized criteria which bring together indicators of economic development, income disparity and the levels of social inequalities in Bulgaria: GDP per capita, Gini coefficient, income inequality, Europa 2020 indicators.

Bulgarian economic development since 1989 has been characterized by considerable fluctuations. There was a stage (1990 - 1997) of economic collapse with 
decrease $^{2}$ of the Gross Domestic Product by approximately 25.6-31\% (Agentsia za ikonomicheski analizi i prognozi [Agency for economic analyses and forecasts], 2005, p. 6; Hristov, 2009, p. 12)ㄹ. From 1999 to 2008 Bulgarian GDP grew regularly, remaining between $4.2 \%$ and $7 \%$ per year: more than twice greater than the EU average. The upward trend was broken by the world financial crisis in 2008. After a GDP decrease of $3.6 \%$ in 2009, economic growth in Bulgaria has stagnated at $0 \%$ in 2012, $1.8 \%$ in 2014, and then stabilized between 3.9 and 3\% where it remains today (Table 1).

The numbers per se outline a generally positive trend in Bulgarian economic development. At the same time, placing these economic trends within a comparative context paints another picture, leading to far more moderate conclusions, especially when we try to appraise the welfare of the population. In 2000, Bulgarian GDP per capita amounted to $28 \%$ of the EU average and along with Romania (at 26\%) was the lowest for all candidate member states. The subsequent above-average economic growth naturally boosted Bulgarian economy; in 2018, GDP per capita already amounted to $50 \%$ of the EU average. (Table 1). At the same time, in spite of this optimistic trend, Bulgaria along with Romania are the EU members with the least developed economies and lowest living standards. In fact, in comparison to the other new EU members, Bulgaria's welfare has grown relatively little. Over the period in question, Bulgaria has 'caught up' with EU by 22\%, whereas countries such as Estonia, Latvia, Lithuania and Slovakia, which were more economically developed in 2000, have done much better, growing by $28-36 \%$.

Table 1

GDP in purchasing power $(E U-27=100)$

$\begin{array}{lllllllll}2000 & 2007 & 2008 & 2009 & 2010 & 2011 & 2012 & 2018 & \% \text { change* }\end{array}$

\begin{tabular}{llllllllll}
\hline EU-27 & 100 & 100 & 100 & 100 & 100 & 100 & 100 & 100 & \\
\hline Bulgaria & $\mathbf{2 8}$ & $\mathbf{4 0}$ & $\mathbf{4 3}$ & $\mathbf{4 4}$ & $\mathbf{4 4}$ & $\mathbf{4 6}$ & $\mathbf{4 7}$ & $\mathbf{5 0}$ & $\mathbf{2 2}$ \\
\hline Estonia & 45 & 70 & 69 & 63 & 63 & 67 & 68 & 81 & 36 \\
\hline Latvia & 36 & 57 & 58 & 54 & 54 & 58 & 62 & 70 & 34 \\
\hline Lithuania & 40 & 59 & 61 & 55 & 57 & 66 & 70 & 81 & 41 \\
\hline Slovakia & 50 & 68 & 73 & 73 & 73 & 73 & 75 & 78 & 28
\end{tabular}

${ }^{2}$ Compared to 1989.

${ }^{3}$ Also $21.3 \%$ unemployment (1996) and $65.6 \%$ collapse of real income of the population.

* Author's calculations 
Note: Source: Eurostat, 2019, last visited on Sept. 13 2019,

https://ec.europa.eu/eurostat/tgm/table.do?tab=table\&init=1\&plugin=1\&language=en $\underline{\text { \&pcode }=\text { tec } 00114}$

However, this data would remain pointless if not supplemented with an analysis of the trends concerning the existing distribution of wealth in Bulgarian society, that is, the dynamics in income distribution. In that respect, at the beginning of the transition (1989), Bulgaria was among the European countries with the lowest income inequality-its Gini coefficient being 21 (Hristov, 2009, p. 24). Afterwards, there was a clear trend toward a swift and regular increase of income inequalities. From 2003 to 2018, Bulgaria's Gini coefficient rose to 39.6 (Table 2). In a period of 15 years, Bulgaria ended up as the EU member with the highest income inequality.

Table 2

Gini coefficient EU-28 and selected member states

\begin{tabular}{llllll} 
& $\mathbf{2 0 0 0}$ & $\mathbf{2 0 0 8}$ & $\mathbf{2 0 1 6}$ & $\mathbf{2 0 1 7}$ & $\mathbf{2 0 1 8}$ \\
\hline EU 28 & & & 30.8 & 30.7 & \\
\hline Bulgaria & $\mathbf{2 5}$ & $\mathbf{3 5 . 9}$ & $\mathbf{3 7 . 7}$ & $\mathbf{4 0 . 2}$ & $\mathbf{3 9 . 6}$ \\
\hline Germany & 25 & 30.2 & 29.5 & 29.1 & \\
\hline Estonia & 36 & 30.9 & 32.7 & 31.6 & 30.6 \\
\hline Spain & 32 & 32.4 & 34.5 & 34.1 & 33.2 \\
\hline Latvia & 34 & 37.5 & 34.5 & 34.5 & 35.6 \\
\hline Lithuania & 31 & 34.5 & 37.0 & 37.6 & 36.9 \\
\hline Poland & 30 & 32.0 & 29.8 & 29.2 & 27.8 \\
\hline Slovenia & 22 & 23.4 & 24.4 & 23.7 & 23.4 \\
\hline Slovakia & & 23.7 & 24.3 & 23.2 & \\
\hline
\end{tabular}

Note: Source: Eurostat, 2019, last visited on Sept. 13 2019, https://appsso.eurostat.ec.europa.eu/nui/show.do?dataset=ilc di12\&lang=en

The characteristics of this process are equally reinforced by the trends in the income distribution between the $20^{\text {th }}$ percentile of highest-income population and the remaining $80 \%$. At the turn of the century, this indicator amounted to 3.7 (Table 3 ). Until 2018, the income ratio of the upper quintile and the other $80 \%$ increased twofold, reaching 7.6, which is among the highest values in EU-27, along with countries such as Latvia, Spain and Greece. The statistics unequivocally indicate that the opening of the 'scissors' between the highest income group and the remaining 80\% in Bulgaria has been the widest in 2000-2018. 
Table 3

Income distribution inequality (20/80) - EU-28 and selected member states

\begin{tabular}{llllll} 
& 2000 & 2007 & 2016 & 2017 & 2018 \\
\hline EU 28 & & & 5.2 & 5.1 & \\
\hline Euro area & & 4.8 & 5.2 & 5.1 & \\
\hline Bulgaria & 3.7 & 7.0 & 7.7 & 8.2 & 7.66 \\
\hline Greece & 5.8 & 6.0 & 6.6 & 6.1 & 5.51 \\
\hline Spain & 5.4 & 5.5 & 6.6 & 6.6 & 6.03 \\
\hline Latvia & 5.5 & 6.4 & 6.2 & 6.3 & 6.8 \\
\hline
\end{tabular}

Note: Source: Eurostat 2019, last visited on Sept. 13 2019, https://appsso.eurostat.ec.europa.eu/nui/show.do?dataset=ilc_di11\&lang=en

Of course, inequalities are a natural phenomenon in market economies. Their existence cannot in itself be examined as a factor affecting the quality of democracy. Inequalities start exerting an impact on the quality and sustainability of democracy only when they affect major groups of people who live in a state of poverty, risk of poverty and/or social exclusion. Therefore, the present analysis must draw attention to precisely this aspect of inequalities in Bulgaria.

Since 1989, there has been a trend of very high risk of poverty and social exclusion in Bulgaria. In 2002, at the start of the period of stable economic growth, 14\% of Bulgaria's population lived at risk of poverty after social transfers. While this was one of the lowest values across the EU in 2002, it grew by 8 points by 2018 , reaching $22 \%$ : the highest value in the EU (Table 4). This demonstrates that in Bulgaria, economic growth coupled with the increase in income inequality has generated a considerable risk of impoverishment for an increasing portion of the population. The second indicator (population in a situation of severe material deprivation) is most indicative of the horizon of the risk of poverty and material deprivation. In 2006, its value for Bulgaria was 57.6\%. From 2006 to 2010 , the intense economic growth reduced this to $45.7 \%$ for Bulgaria-still far above the EU average (8.4\% in 2008). With the advent of the economic crisis, the positive trend was reversed, witnessing a stagnation in the numbers of people living in a state of severe deprivation. In the period 2016-2018 it dropped to 20.9\%, compared to the 5.9\% EU average for 2018 (Table 4). For the third indicator (population living in a household with very low work intensity), analysing the data for Bulgaria only confirms the general picture of social inequalities and poverty. In 2006, its value was $14.7 \%$ for people ages 0 to 59 -the highest in the EU. We can see 
the same correlation with economic development; in the period up to 2010, due to the increase in labour activity and employment the number fell to $8 \%$, which is below the EU average. The years from 2010 up to and including 2019 draw another parallel. Whereas in 2010, people living in such families amounted to $8 \%$ of the population, their number rose to $11.1 \%$ in 2017 and dropped to $9 \%$ in 2018 (Table 4).

Table 4

Europe 2020 indicators

People at risk of poverty after social transfers (\% of population)

\begin{tabular}{llllll}
\hline TIME & 2002 & 2007 & 2016 & 2017 & 2018 \\
\hline EU 28 & $:$ & $:$ & 17.3 & 16.9 & $:$ \\
\hline Bulgaria & 14 & 22 & 22.9 & 23.4 & 22 \\
\hline Romania & 18 & 24.6 & 25.3 & 23.6 & 23.5 \\
\hline
\end{tabular}

Population in a situation of severe material deprivation ( $\%$ of population)

\begin{tabular}{llllll}
\hline & 2007 & 2010 & 2016 & 2017 & 2018 \\
\hline EU 28 & & 8.4 & 7.5 & 6.6 & 5.9 \\
\hline Bulgaria & 57.6 & 45.7 & 31.9 & 30 & 20.9 \\
\hline
\end{tabular}

People living in households with very low work intensity (\% of population)

\begin{tabular}{llllll}
\hline & 2006 & 2010 & 2016 & 2017 & 2018 \\
\hline EU 28 & & 10.3 & 10.5 & 9.5 & \\
\hline Bulgaria & 14.7 & 8 & 11.9 & 11.1 & 9 \\
\hline
\end{tabular}

Note: Source: Eurostat 2019, Europe 2020 indicators, last visited on Sept. 132019 , https://ec.europa.eu/eurostat/web/europe-2020-indicators/europe-2020strategy/main-tables

The accumulation of these statistics and their analysis permit me to draw a general picture of the dynamics, range and character of the risk of poverty and social exclusion in Bulgaria. They clearly demonstrate that currently, Bulgaria is the EU member with the highest proportion of people living in poverty and/or risk of poverty and social exclusion. Furthermore, this trend has been regular in nature. Thus, at the end of the period of sustainable economic development in Bulgaria, 2008, 44.8\% of the general population lived at risk of poverty and social exclusion, as opposed to about $24 \%$ in the rest of the EU. At the end of 2011, nearly half the Bulgarian population (49.1\%) lived at risk of poverty and social exclusion and in 2018 , the numbers dropped to nearly one third of the population, compared to $22.4 \%$ EU 28 average (Table 5). 
Table 5

Population at risk of poverty and social exclusion: EU-27 and selected member states

\begin{tabular}{llllll} 
& $\mathbf{2 0 0 8}$ & $\mathbf{2 0 1 1}$ & $\mathbf{2 0 1 6}$ & $\mathbf{2 0 1 7}$ & $\mathbf{2 0 1 8}$ \\
\hline EU 28 & & 24.3 & 23.5 & 22.4 & \\
\hline Bulgaria & 44.8 & 49.1 & 40.4 & 38.9 & 32.8 \\
\hline
\end{tabular}

Note: Source: Eurostat, 2019, Europe 2020 indicators, last visited on Sept. 13 2019, https://ec.europa.eu/eurostat/databrowser/view/t2020 50/default/table?lang=en

However, the period since 2000 has marked an undeniable stage of relatively stable and positive development of the Bulgarian economy. We can regard it as a process of growing national welfare. Nevertheless, the trend has taken place on a level that is low compared to the EU average, and despite the relatively positive economic growth, Bulgaria remains the EU member with the lowest living standards. I can also claim that Bulgaria has witnessed an extremely swift process of increasing income inequalities and general fragmentation of the pre-1989 social stratification. The process of increasing inequality in Bulgaria is creating an expanding front of poverty or risk of poverty and social exclusion. Characteristically, the dynamics of this process follow the logic of economic development fluctuations. Thus, at times of economic growth the risk of poverty and social exclusion decreases, without, however, changing significantly the high numbers of population groups threatened by poverty. In fact, even during the years of economic growth, the indices of the risk of poverty and social exclusion in Bulgaria are among the highest across EU-28.

\section{Public perception of inequality in Bulgaria}

The previous conclusions may justify us in claiming that in a comparative context, Bulgarian society has been marked by processes of increasing inequalities and a broad front of the risk of poverty and social exclusion, but they provide no answers as to whether the examined trends will be recognized as a significant issue by the population. Of course, looking for established attitudes and opinions among the general population poses its risks and always implies a certain degree of subjectivity. However, this (unclear as to what the 'this' refers to.) does negate their existence and persistence, much less depreciate the significant role they play in forming an overall view of a particular reality and motivating the political conduct and participation of citizens. 
A logical entry point is to seek an answer to the question to what degree poverty and the risk of social exclusion have been reflected in public attitudes and how the Bulgarian public views their existence as a whole. A 2010 study revealed that in their subjective opinions, $59 \%$ of Bulgarians saw themselves as poor, $32 \%$ as average, and only 8\% as rich (Alfa Risarch [Alfa Research], 2010, p. 2). The same or even more pessimistic approaches characterize the period from 2010 to 2013. Thus, Bulgarians who perceive their material situation as very good constituted $1 \%$ of the population in $2010,1.3 \%$ in 2012 , and a mere $0.2 \%$ in 2013 . Those who see their own status as normal (i.e. not poor) were $30.3 \%$ in $2010,26.2 \%$ in 2012 , and $25.1 \%$ in 2013 . The majority place themselves at the other end of the scale, with 45.4\% (in 2010), resp. 47.7\% (in 2013) claiming to have a hard life, and 23.3\% (in 2010), resp. 26.9\% (in 2013) claiming to barely make ends meet (Table 6). In sum, over $70 \%$ of Bulgarians define their own status as poor or relatively poor. It is striking that these pessimistic self-evaluations far exceed the real statistical data which are tied to concrete criteria and poverty lines.

Table 6

How do you evaluate your material situation?

\begin{tabular}{llll} 
& 2010 & 2012 & 2013 \\
\hline Very good & 1.0 & 1.3 & 0.2 \\
\hline Normal & 30.3 & 2.2 & 25.1 \\
\hline Hard & 45.4 & 49.2 & 47.7 \\
\hline I barely make ends meet & 23,3 & 23,2 & 26,9 \\
\hline & $100 \%$ & $100 \%$ & $100 \%$ \\
\hline
\end{tabular}

Note: Source: Mediana, 2013

The data do not change considerably even when self-evaluation becomes more differentiated. The respondents to a 2012 representative survey by Mediana, given the opportunity to define the material situation of their family on a broad scale, confirmed this trend. A mere $11.9 \%$ of people placed their families between the middle of the scale and its high end. Over 88\% regarded themselves as occupying the area between a disastrous material situation and the middle of the scale (Table 7). 
Table 7

On a scale of 1 to 10, please evaluate your and your family's material situation.

\begin{tabular}{ll} 
& \% of all participants \\
\hline 1. & 4.9 \\
\hline 2 & 13.8 \\
\hline 3 & 23.0 \\
\hline 4 & 24.1 \\
\hline 5 & 22.4 \\
\hline 6 & 7.8 \\
\hline 7 & 2.9 \\
\hline 8 & 1.1 \\
\hline 10. & 0.0 \\
\hline & 0.1 \\
\hline
\end{tabular}

Note: 1 - extremely poor, 10 - extremely well-to-do in terms of material situation. Source: Mediana, 2012

Given such evaluations, it is no surprise that Bulgarians consider poverty to be a major problem and mention it very frequently in public surveys. In 2012, a poll conducted by the Open Society Institute revealed that according to Bulgarians, the dominant social problems are related to the risk of poverty. Thus, for $66.5 \%$ of the respondents, the leading problem is low wages. Unemployment garnered a similar number: 63.9\%. Although less prominent, other poverty factors were also present among the top ten problems: poor economy, 32.1\%, and poor education, $7.5 \%$ (Institut Otvoreno Obsthestvo [Open Society Institute], 2012, p. 10). Public opinion attributed poverty to the following five major factors: unemployment, $67 \%$; unfair wages, $47 \%$; social injustice, $35 \%$; health problems, $29 \%$; lack of adequate education, $27 \%$. One most recent poll of Open Society Institute revealed that according to Bulgarians the dominant problems in the country in 2018 were poverty (32\%) and unemployment (18\%) (Institut Otvoreno Obsthestvo [Open Society Institute], 2019, p. 5).

It is also quite revealing to examine public opinion about the efficiency of existing social programmes for the poor and about the actual role that public policy plays in mitigating poverty. The data demonstrate that the majority of the population believes such policies do not exist or even if they do, they do not perform their functions and offer no support in the event of ending up in a dire material situation. Thus, only $9 \%$ of the respondents believe they can rely on state support in case of extreme poverty. Over half of the Bulgarians (67.9\%) categorically state that they cannot rely on such support, and $23 \%$ remain undecided. The same attitude applies to 
local authorities. Again, only $9.7 \%$ believe that they can rely on their municipality in such a situation, whereas $67.2 \%$ say they cannot, and 23\% provide no answer (Table 8). To make matters even more obvious, most respondents list the traditional structures of family and the extended circle of relatives and friends as their major source of safety and support in such circumstances. The notion that there is no effective institutional support makes the majority, $62 \%$, of Bulgarians place their hopes on families, relatives and friends in the event of poverty.

Table 8

Can we rely on external help?

Do you believe that the state will help you if you go bankrupt and end up in a dire material situation?

\begin{tabular}{ll}
\hline & $\%$ of all respondents \\
\hline Yes & 9.0 \\
\hline No & 67.9 \\
\hline I do not know / cannot say & 23.0 \\
\hline
\end{tabular}

Do you believe that the municipality will help you if you go bankrupt and end up in a dire material situation?

\begin{tabular}{ll}
\hline & $\%$ of all respondents \\
\hline Yes & 9.7 \\
\hline No & 67.2 \\
\hline I do not know / cannot say & 23.0 \\
\hline
\end{tabular}

Do you have relatives and friends you will depend upon to help you if you go bankrupt and end up in a dire material situation?

\begin{tabular}{ll}
\hline & $\%$ of all respondents \\
\hline Yes & 62.0 \\
\hline No & 24.7 \\
\hline I do not know / cannot say & 13.3 \\
\hline
\end{tabular}

Note: Source: Mediana, 2012

As I noted above, however, the factors that form the public image and perception of inequalities and poverty are not essential to this section. What matters are the actual opinions and attitudes of Bulgarian society in these regards. The analysis of social opinion not only confirms the scope of inequalities and poverty described in the previous section, but also demonstrates that Bulgarian society treats them as problems of paramount importance. 


\section{Social inequality in Bulgaria and attitudes towards democracy}

The presentation of social inequalities and their public perception in Bulgaria in the previous sections allows me to steer the present study to determining how they affect the attitude toward Bulgarian democracy. I believe, it is important to note that in the context specific to Bulgaria since 1989, that democracy has been construed as a collective concept embodying not only the results of the transition, but also the development perspectives for the country. Against this backdrop, the high level of inequalities in welfare distribution and the wide front of the risk of poverty and social exclusion in Bulgarian society imply not only the need for evaluation but also the existence of a considerable field of probably negative influences on the future sustainability and quality of Bulgarian democracy. The present section aims to outline the impact of the socio-economic environment (social inequalities) on attitudes towards democracy, mostly concerning its legitimacy as a model of sustainable social development in Bulgaria.

It could be argued that with the growing number of democratic regimes around the world, the question of the legitimacy of democracy appears to have lost its relevance. Nevertheless, this question, to me, seems appropriate in the case of Bulgaria and most countries who have undergone a recent democratic transition. This is caused not only by the fact that in countries like Bulgaria, the transition to democracy has been related to the rapid disintegration of former social statuses and the emergence of a society with a high degree of social exclusion and poverty, but also by the ambivalent assessment of the past. Or as Steven Friedman says, 'For the present, citizens of new democracies do seem to have concluded that freedom is preferable to bondage, even if it widens the gulf between those who have and those who do not. But it is at least possible that this has much to do with recent memories of authoritarianism and that, if current trends in the distribution of resources, opportunities and capabilities continue, or even if they are not significantly reversed, the next generation may find continued or growing inequality less tolerable than an authoritarianism that they have ever experienced.' (Friedman, 2002, pp. 15-16)

Friedman's argument provides me with a direction for interpreting the impact of Bulgarian social inequalities on the attitude towards democracy. Are there grounds to 
believe that the accumulating high levels of social inequalities in the country undermine the legitimacy of democracy as a model for sustainable development? With such a formulation of the question, I believe it is important to distinguish between two dimensions in the search for its answer. First, it is vital to determine the general position of Bulgarian citizens regarding democracy. It is necessary to highlight the common trends and attitudes: how is the current situation perceived, provided that democracy is a collective concept for all post-1989 changes in Bulgaria; is there a clearcut consensus about accepting democracy as a successful model for social development or not. Second, I should look for any correlations (or lack thereof) and impact of existing social inequalities and the outlined general attitudes with respect to democracy. The systematic elaboration of these two lines of analysis may pinpoint the possible influences of the socio-economic environment (social inequalities) on Bulgarian democracy.

A brief examination of the transition period reveals that Bulgarians perceive democracy as a generally positive concept. Thus, in 2001, 45.2\% evaluated democracy as a very good form of government, another $41.2 \%$ as good, whereas only $13.2 \%$ saw it as poor or very poor (Hristov, 2007, p. 37). It appears, however, that this attitude has changed over the subsequent period. Ten years later, Bulgarian citizens are more hesitant and divided in this respect. In 2010-2013, 45-47\% answer the same question positively, 22-26\%, negatively, and 28-29\% cannot decide (Table 9).

Table 9

Do you rather agree or disagree with the following statements?

\begin{tabular}{lccc|cccc} 
& \multicolumn{3}{c|}{2010} & \multicolumn{3}{c}{2013} \\
\cline { 2 - 8 } & Yes & No & $\begin{array}{c}\text { Don't } \\
\text { know }\end{array}$ & Yes & No & $\begin{array}{c}\text { Don't } \\
\text { know }\end{array}$ \\
\hline Democracy is the best form of government & 45.2 & 26.6 & 28.2 & 47.6 & 22.9 & 29.5 \\
\hline $\begin{array}{l}\text { Democracy is no good for a country like } \\
\text { Bulgaria }\end{array}$ & 39.4 & 35.5 & 25.1 & 39.8 & 33.6 & 26.5 \\
\hline
\end{tabular}

Note: Source: Mediana, 2013

If the results above apply to approving of democracy in principle, this must indubitably be attributed to the democratic experience accumulated in Bulgaria. The representative sociological polls conducted between 2010 and 2013 demonstrated that Bulgarians clearly understand the nature of the changes related to democracy. The most 
positive benefits have been identified as greater freedom (49\%) and better development perspectives (39.5\%). The opportunity of individuals to assert their positions is also perceived as a gain (26-29\%) (Table 10).

Table 10

Do you rather agree or disagree with the following statements? (\% of all respondents):

\begin{tabular}{|c|c|c|c|c|c|c|c|c|}
\hline & \multicolumn{4}{|c|}{2010} & \multicolumn{4}{|c|}{2013} \\
\hline & Yes & $\begin{array}{c}\text { It's } \\
\text { worse }\end{array}$ & $\begin{array}{l}\text { It's the } \\
\text { same }\end{array}$ & $\begin{array}{l}\text { Don't } \\
\text { know }\end{array}$ & Yes & $\begin{array}{c}\text { It's } \\
\text { worse }\end{array}$ & $\begin{array}{l}\text { It's the } \\
\text { same }\end{array}$ & $\begin{array}{l}\text { Don't } \\
\text { know }\end{array}$ \\
\hline $\begin{array}{l}\text { 1. The present is more } \\
\text { humane. }\end{array}$ & 11.1 & 54.4 & 17.6 & 16.9 & 14.5 & 49.6 & 16.8 & 19.1 \\
\hline 2. The present is fairer. & 11.6 & 53.7 & 18.6 & 16.1 & 13.2 & 49.7 & 17.0 & 20.1 \\
\hline 3. The present is richer. & 29.0 & 40.3 & 12.6 & 18.1 & 21.3 & 47.9 & 12.6 & 18.2 \\
\hline 4. I feel freer now. & 48.4 & 24.6 & 12.1 & 14.9 & 48.9 & 23.5 & 11.8 & 15.8 \\
\hline $\begin{array}{l}\text { 5. I have better } \\
\text { prospects now. }\end{array}$ & 37.4 & 33.6 & 11.7 & 17.3 & 39.5 & 30.5 & 10.2 & 19.8 \\
\hline 6. I feel safer now. & 9.2 & 62.5 & 13.0 & 15.4 & 8.2 & 62.1 & 12.5 & 17.3 \\
\hline 7. I feel better now. & 12.8 & 53.8 & 14.9 & 18.5 & 13.5 & 56.2 & 10.9 & 19.4 \\
\hline $\begin{array}{l}\text { 8. The voice of ordinary } \\
\text { people can be heard } \\
\text { more easily now. }\end{array}$ & 26.0 & 34.4 & 20.0 & 19.6 & 29.5 & 33.1 & 16.7 & 20.7 \\
\hline
\end{tabular}

Note: Source: Mediana, 2013

In contrast, all other dimensions of change are linked to mostly negative or insufficient development in comparison to the former socialist period. This conclusion is based on observing that $49-54 \%$ of Bulgarians believe that the socialist society was more humane and fairer than the democratic one; only $11-14 \%$ hold the opposite opinion, while $17-18 \%$ see no significant change. The assessment of democracy as a period of sustainable development and welfare accumulation is similarly important. Only $21-29 \%$ of the population believe that the democratic society is richer than the socialist one. $40-47 \%$ counter that they are now poorer, $12 \%$ perceive no obvious difference, and 18\% cannot decide (Table 10). These data, although generalized, indubitably point to a predominantly hesitant and negative assessment of what the transition achieved as well as the present level of welfare in Bulgarian society. 
In the context of these evaluations, if we ask the question whether democracy is good for a country like Bulgaria, 2013 witnesses a draw between negative and positive answers. Just over 39\% of Bulgarians maintain that democracy is not good for their country, approximately 34-35\% hold the contrary opinion, and a considerable group of $22-23 \%$ cannot provide a clear answer (Table 11). A more thorough scrutiny of the data reveals the presence of significant generational and education-level diversity, without changing the overall hesitant assessment of democracy. The age groups 18-30 and 3140 demonstrate the highest degree of support for democracy-respectively by 48.1 and 45.5\%, against 19.9 and $27.8 \%$ negative opinions, and 32 and $26 \%$ withholding an answer. Perhaps most telling for the future is the relatively high fraction of uncertainty among youth (18-30 - 32\%), which implies that the democratic experience gathered by the generation that has never been aware of the totalitarian reality is largely contradictory and ambivalent. The assessment of the age groups 51-60 and 60+ forms a distinct contrast: their negative evaluation of democracy is respectively 40 and $46 \%$ (Table 11). Similar conclusions can be drawn from the presence of the same differences in attitude to Bulgarian democracy among the distinct educational-degree groups. The groups of people with secondary or higher education are characterized by a relatively high evaluation: respectively 40.3 and 49.8\%. Bulgarians with primary or lower education occupy the other end of the spectrum: disapproving of democracy by 43.2 and $41.5 \%$ respectively.

Table 11

Do you think democracy rather benefits or harms a country like Bulgaria?

\begin{tabular}{llllll} 
& \multicolumn{3}{c}{ Educational degree } & Average \\
\cline { 2 - 5 } & University & High school & Primary & Lower & \\
\cline { 2 - 5 } $\begin{array}{l}\text { Rather } \\
\text { benefits }\end{array}$ & $49.8 \%$ & $40.3 \%$ & $26.2 \%$ & $9.8 \%$ & $38.6 \%$ \\
\hline $\begin{array}{l}\text { Rather } \\
\text { harms }\end{array}$ & $27.1 \%$ & $34.1 \%$ & $43.2 \%$ & $41.5 \%$ & $34.5 \%$ \\
\hline $\begin{array}{l}\text { I cannot } \\
\text { decide }\end{array}$ & $23.1 \%$ & $25.7 \%$ & $30.6 \%$ & $48.8 \%$ & $27.0 \%$ \\
\hline
\end{tabular}

\begin{tabular}{lllllll} 
& \multicolumn{5}{c}{ Age groups } & Average \\
\cline { 2 - 6 } & $18-30$ & $31-40$ & $41-50$ & $51-60$ & $60+$ & \\
\cline { 2 - 6 } $\begin{array}{l}\text { Rather } \\
\text { benefits }\end{array}$ & $48.1 \%$ & $45.5 \%$ & $39.6 \%$ & $34.9 \%$ & $29.5 \%$ & $38.6 \%$ \\
\hline $\begin{array}{l}\text { Rather } \\
\text { harms }\end{array}$ & $19.9 \%$ & $27.8 \%$ & $31.8 \%$ & $39.9 \%$ & $46.5 \%$ & $34.5 \%$ \\
\hline $\begin{array}{l}\text { I cannot } \\
\text { decide }\end{array}$ & $32.0 \%$ & $26.7 \%$ & $28.6 \%$ & $25.2 \%$ & $24.0 \%$ & $27.0 \%$ \\
\hline
\end{tabular}

Note: Source: Mediana, 2013 
We may also note that Bulgarians do not subscribe to a clear-cut and categorical evaluation of the socialist period. More than twenty years into the transition, a comparison between the former regime and the democratic rule elicits divided opinions. Thus, in 2013, 35.3\% of Bulgarians not only harbour no negative feelings about the pre-1989 period, but would also welcome the restoration of the former regime. Nearly the same percentage, $31.3 \%$, prefer the current democratic government, and the remaining third, $33.4 \%$, cannot make up their minds about the advantages and disadvantages of the two regimes (Table 12).

Table 12

If it were up to you, would you restore the former system (prior to 10 November 1989) or do you prefer the present one?

\begin{tabular}{lll}
\hline I would restore the former one & 2010 & 2013 \\
\hline I prefer the present one & 33.6 & 35.3 \\
\hline I cannot say & 35.5 & 31.3 \\
\hline & 30.9 & 33.4 \\
\hline
\end{tabular}

Note: Source: Mediana, 2013

The observed trends can be partially explained by various researchers' claim that there exists some nostalgia for the totalitarian years (Hristov, 2009, p. 36). Indeed, in Bulgaria's case, we must take into consideration the relatively recent establishment of democracy. This fact, although not a major factor for the attitude towards democracy, has its importance and impact. To say the least, part of contemporary Bulgarian society consists of generations who have not only spent a considerable portion of their lives during socialist times, but cherish relatively positive memories and assessment of their lifestyle then. The very fact that such a sentimentality exists does not, however, imply that it should be evaluated only in its irrational context, disregarding the possible existence of rational dimensions. A point in case, especially for the elderly generations, is the fact that these age groups include the people who have not only lived most of their life in the totalitarian period but are also the individuals (e.g. retired people) who have been affected the worst by poverty and the risk of social exclusion. A similar, though less encompassing, reasoning can be extended to the existence of a considerable group of youth who do not have an explicit view of democracy as a sustainable and useful model for development of Bulgaria. This is particularly relevant to people aged $16-24$, where the level of the risk of poverty and social exclusion was $33.3 \%$ in 2018 (Eurostat, 2019). 
If we pursue these reflections further, we must also look for other factors to account for the described assessments and attitudes towards Bulgarian democracy. One of them relates directly to the nature and scope of the social inequalities and the process of losing social status, regarded as direct consequences of the transition and the operation of Bulgarian democratic society. The correlation is easy to observe, repeating across all of the aforementioned dimensions of people's attitude to democracy. In that respect, the positive and negative appraisals of the post-1989 changes exhibit a strong correlation with the material situation of Bulgarians and their self-evaluation of their social status. The groups who perceive their material situation as hard or extremely hard ('I have a hard life' and 'I barely make ends meet') also offer the most negative evaluation of Bulgarian democratic society. As a matter of fact, the general attitude of all Bulgarians tends to be pessimistic and negative in this respect. Thus, $50 \%$ of those who believe they have a very good life claim that the present society is less humane, less fair and less rich than the pre-1989 one. The other $50 \%$ of this group say there are no obvious differences (Table 13). The group of Bulgarians who believe their life is normal is the one that offers the most positive attitude to the characteristics of the established democratic society. $26.4 \%$ of them consider the present society to be more humane, $25.7 \%$ see it as fairer, and $32.8 \%$, as richer (Table 13). This positive assessment is not so prominent and remains restricted mostly to that portion of the population that may be said to have benefited from the transition, accounting for a relatively minor part of all Bulgarians - 25-30\%.

In contrast, the groups evaluating their material situation as hard or very hard ('I have a hard life', 'I barely make ends meet') offer an explicitly negative opinion. A small fraction of them, 12.1\% ('I have a hard life') and 7.7\% ('I barely make ends meet'), perceive the present society as more humane. The majority hold the opposing view, $54 \%$ and $57.9 \%$ respectively. $19.4 \%$, resp. $12.9 \%$ see no difference between the democratic and the socialist societies, and 14.6\%, resp. $21.4 \%$ cannot make up their minds. The same attitudes apply to fairness in post-1989 society. 53.1\% ('I have a hard life') and 61\% ('I barely make ends meet') claim that the democratic society is less fair than the socialist one; $20.6 \%$, resp. $11 \%$ see no difference; and $15 \%$, resp. $21.4 \%$ cannot say for sure. The question whether the present society is richer than the previous one produces similar responses. More than half the participants from these two groups 
( $50.1 \%$ and $58.3 \%$ respectively) believe that the present society is poorer than the pre1989 one; $13.4 \%$, resp. $11.4 \%$ see no difference in their material situation over the two periods; and 15.7\%, resp. 19.2\% offer no categorical opinion. (Table 13)

Table 13

Self-evaluation of one's material situation with respect to the present society as compared to pre-1989 times

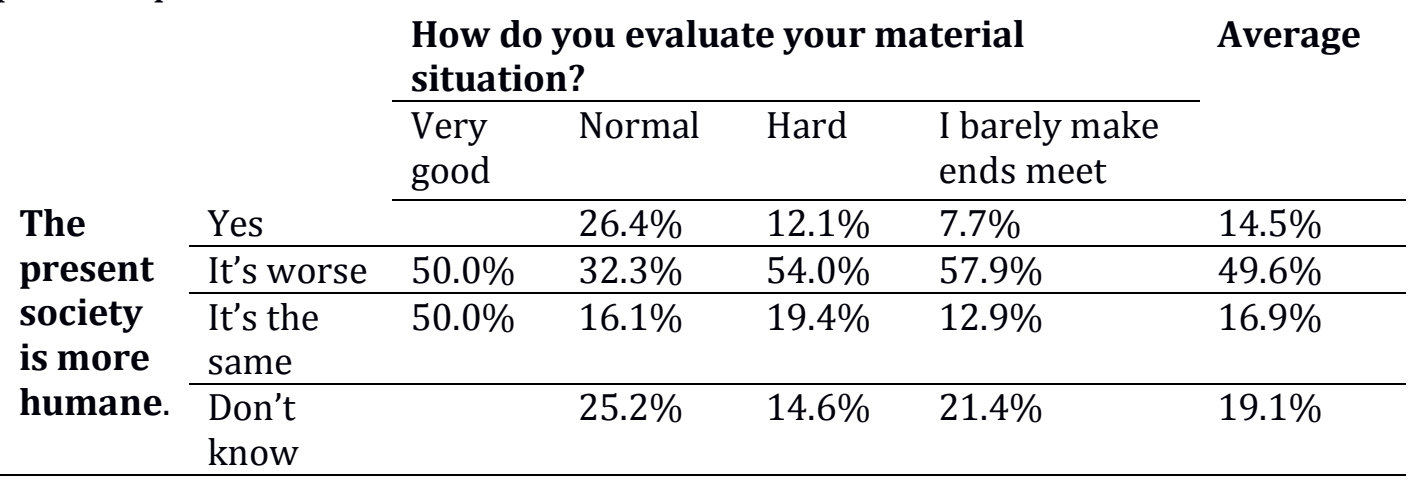

\begin{tabular}{|c|c|c|c|c|c|c|}
\hline \multirow{5}{*}{$\begin{array}{l}\text { The } \\
\text { present } \\
\text { society } \\
\text { is fairer. }\end{array}$} & \multirow[b]{3}{*}{ Yes } & \multicolumn{4}{|c|}{$\begin{array}{l}\text { How do you evaluate your material } \\
\text { situation? }\end{array}$} & \multirow[t]{2}{*}{ Average } \\
\hline & & \multirow[t]{2}{*}{$\begin{array}{l}\text { Very } \\
\text { good }\end{array}$} & \multirow{2}{*}{$\begin{array}{l}\text { Normal } \\
25.7 \% \\
\end{array}$} & \multirow{2}{*}{$\begin{array}{l}\text { Hard } \\
11.3 \%\end{array}$} & \multirow{2}{*}{$\begin{array}{l}\text { I barely make } \\
\text { ends meet }\end{array}$} & \\
\hline & & & & & & $13.2 \%$ \\
\hline & It's worse & $50.0 \%$ & $30.8 \%$ & $53.1 \%$ & $61.5 \%$ & $49.8 \%$ \\
\hline & $\begin{array}{l}\text { It's the } \\
\text { same }\end{array}$ & $50.0 \%$ & $15.4 \%$ & $20.6 \%$ & $11.5 \%$ & $16.9 \%$ \\
\hline & $\begin{array}{l}\text { Don't } \\
\text { know }\end{array}$ & & $28.1 \%$ & $15.0 \%$ & $21.9 \%$ & $20.1 \%$ \\
\hline
\end{tabular}

\begin{tabular}{|c|c|c|c|c|c|c|}
\hline & & $\begin{array}{l}\text { How d } \\
\text { situati }\end{array}$ & $\begin{array}{l}\text { you evalu } \\
\text { ? }\end{array}$ & e your & terial & Average \\
\hline & & $\begin{array}{l}\text { Very } \\
\text { good }\end{array}$ & Normal & Hard & $\begin{array}{l}\text { I barely make } \\
\text { ends meet }\end{array}$ & \\
\hline The & Yes & & $32.8 \%$ & $20.9 \%$ & $11.1 \%$ & $21.2 \%$ \\
\hline present & It's worse & $50.0 \%$ & $33.2 \%$ & $50.1 \%$ & $58.3 \%$ & $48.1 \%$ \\
\hline $\begin{array}{l}\text { society } \\
\text { is }\end{array}$ & $\begin{array}{l}\text { It's the } \\
\text { same }\end{array}$ & $50.0 \%$ & $11.5 \%$ & $13.4 \%$ & $11.4 \%$ & $12.4 \%$ \\
\hline richer. & $\begin{array}{l}\text { Don't } \\
\text { know }\end{array}$ & & $22.5 \%$ & $15.7 \%$ & $19.2 \%$ & $18.3 \%$ \\
\hline
\end{tabular}

Note: Source: Mediana, 2013

The presence of a correlation between existing social inequalities and the risk of poverty on the one hand, and the legitimacy of democracy on the other, is confirmed by the overall attitude to democracy and the assessment of its usefulness and appropriateness as a model for sustainable development in Bulgaria. Here, the influence of social inequalities and Bulgarians' self-evaluation of their material situation is even 
more prominent, forming two distinct groups. The democratic regime is perceived as a good option for the development of Bulgaria by those Bulgarians who assess their material situation and social status as very good or normal. Thus, this group mostly rejects the proposition that democracy is no good for a country like Bulgaria. The respondents who evaluate their material condition as very good provide the greatest support: 66.7\%; among them, there are no negative opinions (Table 14). The second income group, assessing their material situation as normal, displays similar attitudes, although with some obvious differences. The greatest portion of these participants $(47 \%)$ regard democracy as a good thing for a country like Bulgaria, and another $22.1 \%$ would categorize it as neither good nor bad. However, in this group, there is also a distinct negative assessment of democracy, expressed by $30.8 \%$ (Table 14).

Table 14

Democracy is no good for a country like Bulgaria' against self-evaluation of one's material situation

\begin{tabular}{|c|c|c|c|c|c|c|}
\hline \multirow{6}{*}{$\begin{array}{l}\text { Democracy is } \\
\text { no good for a } \\
\text { country like } \\
\text { Bulgaria' }\end{array}$} & \multirow[b]{3}{*}{ It is not } & \multicolumn{4}{|c|}{$\begin{array}{l}\text { How do you evaluate your own material } \\
\text { situation? }\end{array}$} & \multirow[t]{2}{*}{ Average } \\
\hline & & Very good & Normal & Hard & $\begin{array}{l}\text { I barely make } \\
\text { ends meet }\end{array}$ & \\
\hline & & & $30.8 \%$ & $40.8 \%$ & $47.4 \%$ & $39.9 \%$ \\
\hline & It is & $66.7 \%$ & $47.0 \%$ & $35.8 \%$ & $16.7 \%$ & $33.6 \%$ \\
\hline & Don't & $33.3 \%$ & $22.1 \%$ & $23.4 \%$ & $35.9 \%$ & $26.5 \%$ \\
\hline & know & & & & & \\
\hline
\end{tabular}

Note: Source: Mediana, 2013

In contrast, Bulgarians who assess their material situation as hard or very hard ('I have a hard life', 'I barely make ends meet') offer the opposite evaluation of democracy. They express a predominantly negative opinion, with $40.8 \%$ ('I have a hard life') and $47.4 \%$ ('I barely make ends meet') respectively seeing democracy as no good for a country like Bulgaria. Correspondingly, there is an increasingly smaller fraction of people in the two groups approving of democracy: $35.8 \%$ of 'I have a hard life' and a mere $16.7 \%$ of 'I barely make ends meet.' A sizeable portion of these respondents assume a neutral or indeterminate position, amounting to $23.4 \%$ and $35.9 \%$ respectively (Table 14). 
The categorical interpretation of these data is difficult, and it would be unjustified to insist on an explicit rejection of democracy, i.e. a clear-cut tendency for undermining its legitimacy. Nevertheless, the data permit us to claim that nowadays, more than twenty years after the changes and the establishment of the democratic system in Bulgaria, public opinion is far from embracing an unqualified acceptance of democracy. Furthermore, the data and their connection to general attitudes towards democracy demonstrate that the presence of negative trends in the socio-economic development of Bulgaria (growing inequalities, risk of poverty and social exclusion) have a considerable impact on the overall perception of democracy as a successful model of sustainable development.

\section{Conclusions}

Examining the legitimacy of Bulgarian democracy in the context of social inequalities allows us to reach several important conclusions. Firstly, the assessment of Bulgaria according to the initially set criteria provides us with grounds to claim that the country's socio-economic development includes a number of important processes and features that cannot be regarded as beneficial or conducive to the legitimacy and quality of Bulgarian democracy. Over the past twenty years, Bulgaria has been going through a dynamic and profound increase of inequalities, which led to the emergence of a broad front of risk of poverty and social exclusion affecting approximately half of the population. Consequently, Bulgarian public attitudes largely perceive the existing inequalities and risk of poverty as crucial problems. The existing levels of inequalities and risk of poverty indubitably affect the attitude towards democracy. Although we cannot claim that there exists an unequivocally negative public attitude to democracy in Bulgaria, we have witnessed that there does exist a tendency for this attitude to change; as time goes by, it does not veer toward the positive but clearly moves in the direction of decreasing certainty as to accepting democracy as a successful model for societal development. It must be also pointed out that the latest polls of attitudes towards democracy in Bulgaria reveal continuing slow growth of this negative trend. For example, the poll conducted by Open Society institute in 2019 indicates that democracy is supported as the best form of government for Bulgaria by about $45 \%$ of the population - 7\% lower than in 2015 (Institut Otvoreno Obsthtestvo, \{Open Society 
Institute\}, 2019, p. 2). We must therefore conclude that at least on a primary empirical and analytical level, social inequalities and the risk of poverty appear to have a strongly negative impact on the legitimacy of democracy in Bulgaria. Of course, these conclusions can have only a partial significance in the context of the overall study of the quality and legitimacy of democracy in Bulgaria. The answer to that broader and more general question requires the examination of numerous additional dimensions of Bulgarian democracy as well as the selection of criteria to evaluate them and factors to determine their concrete characteristics.

\section{References}

Agentsiya za ikonomicheski analizi i prognozi (2005). Ikonomikata na Balgariya prez 2004 g. (godishen doklad). Ministerstvo na finansite na republika Balgariya. [Agency for economic analyses and forecasts (2004). The Economy of Bulgaria in 2004 (annual report). Ministry of Finance of the Republic of Bulgaria]. Sofia.

Alfa Risarch (2010). Obsthtestvenoto mnenie za bednostta I sotsialnoto izkljuchvane v Balgaria. [Alfa Research (2010). The public's perception towards poverty and social exclusion in Bulgaria]. Sofia.

Bühlman, M., Merkel W. \& Müller, L. (2007). The Quality of Democracy: Democracy Barometer for Established Democracies. Working Paper 10. National Centre of Competence in Research (NCCR). Challenges to Democracy in the $21^{\text {st }}$ Century. NCCR Democracy, Zurich.

Collier, D. \& Levitsky, S. (1996). Democracy "with adjectives". Conceptual innovation in comparative research. Working Paper 230, Kellogg Institute.

Dahl, R. (1971). Polyarchy: Participation and Opposition. USA, Yale University Press.

Erdmann, G. \& Kneuer, M. (2011). Introduction. In Erdmann, G. \& Kneuer, M. (eds.). Regression of Democracy? Comparative governance and politics. Special Issue 1. VS Verlag, Wiesbaden, 9-20. https://doi.org/10.1007/978-3-531-93302-3 1

Eurostat, (2019). GDP per capita in PPS. Eurostat, https://ec.europa.eu/eurostat/tgm/table.do?tab=table\&init=1\&plugin=1\&langu $\underline{\text { age }=\text { en\&pcode }=\text { tec00114 }}$,(last visited on Sept. 13. 2019).

Eurostat, (2019). Gini coefficient of equivalised disposable income - EU-SILC survey. Eurostat, https://appsso.eurostat.ec.europa.eu/nui/show.do?dataset=ilc di12\&lang=en , (last visited on Sept. 13. 2019).

Eurostat, (2019). S80/S20 income quintile share ratio by sex and selected age group EU-SILC and ECHP surveys. Eurostat, https://appsso.eurostat.ec.europa.eu/nui/show.do?dataset=ilc di11\&lang=en , (last visited on Sept. 13. 2019). 
Eurostat, (2019). Europe 2020 indicators/ Main Tables/Poverty and social exclusion. Eurostat, https://ec.europa.eu/eurostat/web/europe-2020-indicators/europe2020-strategy/main-tables, (last visited on Sept. 13. 2019).

Eurostat (2019). People at risk of poverty or social exclusion by age and sex [ilc_peps01. Eurostat, https://appsso.eurostat.ec.europa.eu/nui/submitViewTableAction.do , (last visited on Sept. 3.09.2019).

Friedman, S. (2002). Democracy, Inequality and the Reconstitution of Politics. In: Tulchin, J.S. \& Brown, A. (eds.), Democratic governance and social inequality. Lynne Rienner Publishers, UK, USA, (pp. 13-40).

Hadenius, A. (1992). Democracy and Development. Cambridge. Cambridge University Press. https://doi.org/10.1017/CB09780511549731

Held, D. (1996). Models of Democracy. Cambridge, Cambridge University Press.

Heller, H. (1934). Staatslehre. Herausgegeben von Gerhart Niemeyer.

Heller, H. (1971). Gesammelte Schriften. Leiden: A.W. Sijthoffs Uitgeversmaatschappij N.V.

Hristov, T. (2007). Bulgaria. Deliverable 2. Desk Research. EUREQUAL. Social Inequality and Why It Matters for the Economic and Democratic Development of Europe and Its Citizens: Post-Communist Central and Eastern Europe in Comparative Perspective. Oxford: University of Oxford.

Huntington, S. (1991). Democracy, s third wave. Journal of Democracy, 2(2), 12-34. https://doi.org/10.1353/jod.1991.0016

Institut Otvoreno Obsthtestvo (2012). Obsthestveno mnenie I sotsialni naglasi v Balgaria prez may $2012 \mathrm{~g}$. [Open Society Institute (2012). Public's opinion and social attitudes in Bulgaria in May 2012]. Sofia.

Institut Otvoreno Obsthtestvo (2019). Demokratsiya I grazhdansko uchastie: Obsthestvenite naglasi kam demokratsiyata, varhovenstvoto na pravoto I osnovnite prava na choveka prez 2018 g. [Open Society Institute (2019). Democracy and civil participation: Public's attitudes towards democracy, rule of law and the basic human rights in 2018]. Sofia.

Lauth, H. J. (2004). Demokratie und Demokratiemessung. Eine konzeptionelle Grundlegung für den interkulturellen Vergleich. Wiesbaden: VS Verlag für Sozialwissneschaften. https://doi.org/10.1007/978-3-663-01617-5

Lauth, H. J., Pickel, G. \& Welzel, C. (2000). Grundfragen, Probleme und Perspektiven der Demokratiemessung. In Lauth H.J., Pickel G. \& Welzel C. (eds.). Demokratiemessung. Konzepte und Befunde im internationalen Vergleich (pp. 726). Wiesbaden. Westdeutscher Verlag. https://doi.org/10.1007/978-3-322$\underline{89590-51}$ 
Lipset, S. M. (1981). Political man. The social bases of politics. Baltimore, Maryland: The John Hopkins University Press.

Merkel, W. (2004). Embedded and defective Democracies. Democratization, 11(5), 3358. https://doi.org/10.1080/13510340412331304598

Morlino, L. (2004). “Good „and "bad” democracies: how to conduct research into the quality of democracy. Journal of communist studies and transition politics, 20 (1). Routlege, 5-27. https://doi.org/10.1080/13523270410001687082

O’Donnell, G. (1998). Horizontal Accountability in New Democracies. In: Journal of Democracy, 3 (9), 112-126. https://doi.org/10.1353/jod.1998.0051

O'Donnell, G., Gullel, J. V. \& Lazzetta, M. O. (2004) The quality of democracy: Theory and Applications. Helen Kellogg Institute for International Studies. University of Notre Dame Press.

Rawls, J. (1971). A theory of Justice. Cambridge, Harvard University Press.

Roberts, A. (2010). The quality of democracy in Eastern Europe. Public Preferences and Policy Reforms. Cambridge, New York: Cambridge University Press. https://doi.org/10.1017/CB09780511757365

Rueschemeyer, D. (2004). Addressing Inequality. Journal of Democracy, 15 (4), Johns Hopkins University Press, 76-90. https://doi.org/10.1353/jod.2004.0072

Sen, A. (1979). Equality of what? The Tanner lecture of human values. Stanford University.

Sen, A. (1996). On the status of equality. Political Theory 24(3), 394-400. https://doi.org/10.1177/0090591796024003004

Schumpeter, J. (1943). Capitalism, Socialism and Democracy. London UK: Routledge. 